\title{
DEVELOPMENT OF A MOTORIZED GINGER RHIZOMES PEELING MACHINE
}

\author{
C. G. Arocha ${ }^{1, *}$ and K. J. Simonyan ${ }^{2}$ \\ 1, 2, Department of Agricultural and Bioresources EngineERING, Michael OKPARA University of \\ AGRICULTURE, UMUdiKE, ABIA STATE. NIGERIA \\ E-mail address: ${ }^{1}$ arochachimdi@gmail.com, 2 omogbeka@gmail.com
}

\begin{abstract}
A $5 \mathrm{~kg}$ motorized ginger rhizomes peeling machine was designed and developed. Three moisture contents (70\%, $75 \%$ and $80 \%$ ) wb, three feed rates (54 kg/hr, $68 \mathrm{~kg} / \mathrm{hr}$ and $73 \mathrm{~kg} / \mathrm{hr}$ ) and three peeling speeds (230 rpm, $270 \mathrm{rpm}$ and $300 \mathrm{rpm}$ ) were used to evaluate the performance of the developed machine. $A 3 \times 3 \times 3$ factorial experiment in a randomized complete block design; replicated two times was used to study the effects of the three factors (moisture content, feed rates and peeling speed) on the performance parameters (peeling efficiency, peeling capacity and percent damage). The study showed that peeling efficiency increased with an increase in moisture content and peeling speed and decreased with an increase in feed rate. Peeling capacity decreased with a decrease in moisture content, and increased with an increase in peeling speed. Percent damage decreased with increasing moisture content, increased with an increase in feed rate and peeling speed. For a maximum peeling efficiency, peeling capacity and minimum percent damage, an optimum moisture content of $75 \%$ wb, feed rate of $68 \mathrm{~kg} / \mathrm{hr}$ and peeling speed of $270 \mathrm{rpm}$ are recommended.
\end{abstract}

Key words: Ginger rhizomes, peeling capacity, peeling efficiency, peeling capacity, machine design.

\section{INTRODUCTION}

Ginger (Zingiber Officinale Roscoe) belongs to the plant family of Zingiberraceae. Ginger is a plant with leafy shoots, finger-like perennial underground part or rhizomes called hands and develop to a height of about $1.5 \mathrm{~m}$ with an aerial part as high as $0.8 \mathrm{~m}$ depending on cultivars and growing environment [1]. It is one of the oldest and most important of all the spices and condiments. The major producing areas where the plant is grown in Nigeria, include Kaduna, Nassarawa, Sokoto, Zamfara, AkwaIbom, Oyo, Abia and Lagos states though the largest producers of ginger in Nigeria still remain Southern Kaduna in Kachia, Jabba, Jama'a and Kagarko Local Government Areas [2 - 4].

Dried ginger, whether for use as the ground spice or for the industrial preparation of its derivatives (ginger oleoresin and ginger oil) is valued for its pleasing combination of aroma, flavour and pungency [5].
Primary processing of ginger rhizomes involves operations such as washing, slicing/splitting/peeling and drying [6]. Peeling of ginger is an important unit operation where fully matured rhizomes are scraped with bamboo-splits having pointed ends, to remove the outer skin before drying to accelerate the drying process [7]. Although ginger cultivation in Nigeria started in 1927 [8], peeling which is one of the unit operations in its local processing is still being done predominantly by traditional method (manual scraping with knife) which is labour intensive, full of drudgery and it also exposes the hand to injury. Deep scraping with knife needs to be avoided to prevent damage to oil-bearing cells present just beneath the outer skin. Excessive peeling results in reduction of essential oil content in dried product.

Few industries that process ginger in the country make use of imported machinery (which costs about 2 - 2.9 million Naira compared to the ones fabricated 
locally which cost about $150-200,000$ naira) due to non-availability of simple locally developed machines for its processing and this has adversely affected the production and marketing of ginger in Nigeria, in spite of its great economic potentials. Farmers still resort to processing their ginger using primordial practices inherited from earliest traditions resulting in poor and unhygienic processed ginger [9]. Proper development of ginger peeling machine is the important and necessary step in unit operation as this is an essential process to accelerate the drying process of the product.

Jayashree and Visvanathan [7] developed a concentric drum brush type ginger peeler with a capacity to peel $7 \mathrm{~kg}$ per batch. The optimum operating conditions for peeling ginger were obtained at drum load of $7 \mathrm{~kg}$, for inner drum speed of $45 \mathrm{rpm}$, outer drum speed of $20 \mathrm{rpm}$ and for a peeling duration of 15 minutes. The peeling efficiency was $61 \%$ and the corresponding material loss was $5.33 \%$. A brush type ginger peeling machine with two continuous brush belts moving vertically in opposite direction was reported by [10]. The maximum peeling efficiency obtained for the brush type ginger peeling machine was $84.3 \%$ at a belt speed of $85 \mathrm{rpm}$ having a belt spacing of $1 \mathrm{~cm}$.

Yiljep, et. al [11] reported the development of an abrasive brush type ginger peeling machine consisting of two continuous vertical belts provided with 32-gauge steel wire brush, $2 \mathrm{~cm}$ long and having a peeling zone of $135 \mathrm{~cm}$, had a maximum peeling efficiency of $85 \%$. Despite all the developments in ginger peeling machine, the farmers still fall back to the manual method of peeling. This usually results in low processing output of ginger products by the farmers which eventually yield little or no return. This is because of high level of drudgery associated with the manual method which entails using bamboo or knife thereby making the production to be subsistence [8].

This has necessitated proper design, development and performance evaluation of ginger peeling machine for easy processing of ginger and its products. This will enable a full recovery of oil or juice from the product and increase the availability of the products being produced from ginger. Since ginger is an important crop of commerce, mechanization in various handling operations is of urgent need. The machine will improve the post-harvest quantity and quality of peeled dried ginger, and also encourage production of ginger rhizomes in the country.

\section{MATERIALS AND METHODS}

\subsection{Design Considerations}

In order to obtain high efficiency and reliability, the machine was designed based on the following considerations.
i. Made from readily available materials.
ii. Cheap and within the buying capacity of local farmers.
iii. Able to peel different varieties, shapes and sizes of ginger.
iv. High in capacity compared to manual operations.
v. Able to reduce drudgery in traditional method of peeling.

\subsection{Description of Developed Ginger Rhizome Peeling Machine}

The motorized ginger rhizomes peeling machine consists of the following components: frame, feeding unit, pulley and belt drive, shoe pad, arm, shaft, connecting rod, discharge chute and gate. Figure 1 and 2 show the developed ginger peeling machine and orthographic views of peeling machine.

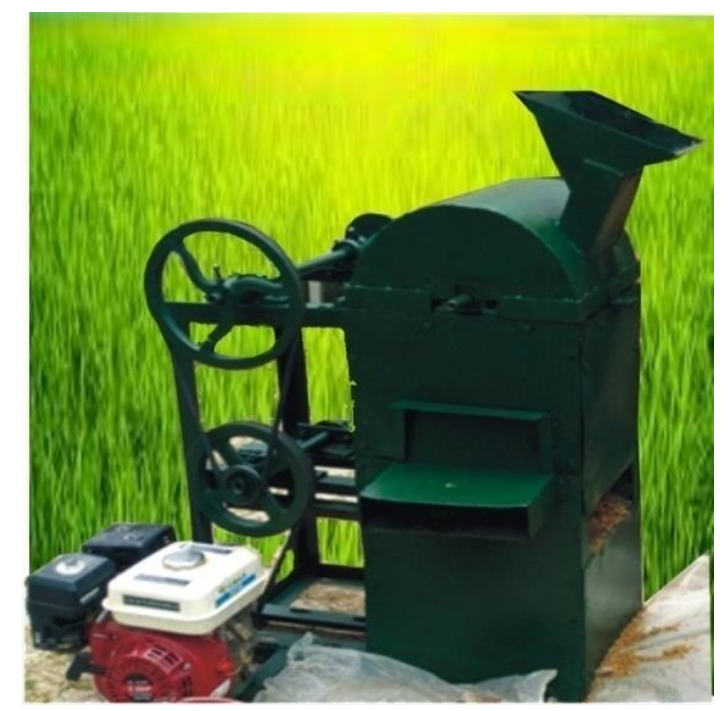

Figure 1: Developed ginger rhizomes peeling machine

\subsubsection{Frame}

The frame holds all the components of the ginger peeling device. It is designed to withstand torsional and vibrational forces. It has a length of $800 \mathrm{~mm}$, width of $400 \mathrm{~mm}$ and height of $830 \mathrm{~mm}$.

\subsubsection{Feeding Unit (Hopper)}

The hopper feeds the ginger rhizomes into the peeling chamber where rhizomes are subjected to 
peeling action from the abrasive shoe pad that got action from the shaft rotation. It has a dimension of $300 \times 230 \mathrm{~mm}$ and inclined at angle of $40^{\circ}$.

\subsubsection{Pulley and Belt Drive}

The pulleys which have diameters of $85 \mathrm{~mm}, 250 \mathrm{~mm}$ and $300 \mathrm{~mm}$ transmit the mechanical energy from the shaft of combustion engine to the shaft of the ginger rhizome peeler.

\subsubsection{Shoe Pad}

This is the component that comes into direct contact with the ginger rhizomes and provides the frictional force for the peeling. The shoe $(118 \mathrm{~mm})$ is made-up of stainless wire gauze material which has a rough surface. This material is attached to a flat bar using bolts and nuts for ease of replacement.

\subsubsection{Arm}

The arm is the component of the machine which carries the shoe for the peeling. It is joined to the shaft by welding. It has a hollow pipe which is welded to the shaft and then a solid part which slides inside the hollow pipe in order to change the clearance. The solid arm $(200 \mathrm{~mm})$ is held firmly to the hollow pipe by screw after adjusting to the suitable clearance. The adjustment is to accommodate for the variation in the sizes of the ginger rhizomes.

\subsubsection{Shaft}

The shaft of the ginger rhizome peeling machine transmits the mechanical energy that will be transmitted from the combustion engine through the pulley and belt drive system to the oscillating shoe pad which has a length of $620 \mathrm{~mm}$ and a diameter of $25 \mathrm{~mm}$.

\subsubsection{Connecting Rod}

This transmits rotary motion given to the shaft by the motor to oscillating motion of the shoe pad which has a length of $480 \mathrm{~mm}$.

\subsubsection{Discharge Chute}

Discharge chute is an extension of the peeling unit whereby the peels of the ginger rhizomes are discharged under gravity as they are being peeled. It has a dimension of $115 \mathrm{~mm}$ length, $300 \mathrm{~mm}$ width and angle of inclination of $65^{\circ}$.

\subsubsection{Discharge Gate}

It is a casing of $80 \mathrm{~mm}$ length and $305 \mathrm{~mm}$ width covering the peeling chamber which is inclined at an angle of $46^{\circ}$ so that during the peeling operation the rhizomes do not splatter, rather its being opened after the operation for collection of the peeled ginger rhizomes.

\subsection{Determination of force required to peel the ginger rhizomes}

The force required to peel the ginger rhizome was determined using the expression given by [12] as shown below:

$$
F=\frac{\tau}{r}
$$

where: $F$ is force $(N)$, $T$ is torque $(\mathrm{Nmm})$ and $r$ is radius of the driving pulley $(\mathrm{mm})$

But;

$$
\tau=\frac{P}{\omega}
$$

where: $P$ is power of prime mover $(W)$ and $\omega$ is angular velocity ( $\mathrm{rad} / \mathrm{sec})$

$$
P=\frac{2 \pi N \tau}{60}=\tau \omega
$$

Given that: $\mathrm{P}$ is $4103 \mathrm{~W}, \mathrm{~N}$ is $3600 \mathrm{rpm}$, and $\mathrm{r}$ is 37.5 $\mathrm{mm}$

$\tau=10.88 \mathrm{Nmand} F=0.29 \mathrm{~N}$

\subsection{Determination of belt length}

This is the length of the belt between the prime mover pulley and the peeling shaft pulley was determined using the expression given by [13]:

$$
L=2 C+\frac{1.57\left(D_{1}+D_{2}\right)}{2}+\frac{\left(D_{1}+D_{2}\right)^{2}}{4 C}
$$

where: $L$ is the length of the belt $(\mathrm{mm})$ and $C$ is center distance of the belt $(\mathrm{mm})$

For the center pulley, given that: $C$ is $300 \mathrm{~mm}, D_{1}$ is $75 \mathrm{~mm}$ and $D_{2}$ is $250 \mathrm{~mm}$

$\therefore L=943.15 \mathrm{~mm}$

For the upper pulley, given that: $C$ is $370 \mathrm{~mm}, D_{1}$ is $85 \mathrm{~mm}$ and $\mathrm{D}_{2}$ is $300 \mathrm{~mm}$

$\therefore L=1142.38 \mathrm{~mm}$

\subsection{Determination of ginger rhizome peeling speed}

Peeling speed was determined using equations 4-6 given by [14]:

$$
\begin{aligned}
& N_{1} D_{1}=N_{2} D_{2} \\
& N_{3} D_{3}=N_{4} D_{4} \\
& N_{5} D_{5}=N_{6} D_{6}
\end{aligned}
$$


where: $N_{1}$ is prime mover speed (rpm), $N_{2}$ is speed of larger center pulley (rpm), $D_{1}$ is diameter of prime mover pulley $(\mathrm{mm}), \mathrm{D}_{2}$ is diameter of larger center pulley $(\mathrm{mm}), \mathrm{N}_{3}$ is speed of smaller center pulley $(\mathrm{rpm}), \mathrm{D}_{3}$ is diameter of smaller center pulley $(\mathrm{mm})$, $\mathrm{D}_{4}$ is diameter of larger (upper) pulley $(\mathrm{mm}), \mathrm{N}_{4}$ is speed of larger (upper) pulley (rpm), $\mathrm{N}_{5}$ is speed of smaller cam (rpm), $D_{5}$ is diameter of smaller cam (rpm), $N_{6}$ is speed of larger cam connected to peeling shaft (rpm) and $D_{6}$ is diameter of larger cam connected to peeling shaft (rpm)

Given that: $N_{1}$ is $3600 \mathrm{rpm}, D_{1}$ is $75 \mathrm{~mm}, D_{2}$ is 250 $\mathrm{mm}$ and $\mathrm{N}_{2}$ is?

$\therefore N_{2}=1080 \mathrm{rpm}$

Given that: $N_{3}=N_{2}$ is $1080 \mathrm{rpm}, D_{3}$ is $85 \mathrm{~mm}, D_{4}$ is $300 \mathrm{~mm}$ and $\mathrm{N}_{4}$ is?

$\therefore N_{4}=306 r p m$

Given that: $N_{5}$ is $306 r p m, D_{5}$ is $150 \mathrm{~mm}, D_{6}$ is

$200 \mathrm{~mm}$ and $\mathrm{N}_{6}$ is?

$\therefore N_{6}=230 \mathrm{rpm}$

\subsection{Working Principle of Developed Ginger Peeling Machine}

The kinematics upon which the machine works is the principle of quadric-crank mechanism. This principle converts rotary motion to oscillatory motion, whereas the force application for peeling uses the principle of
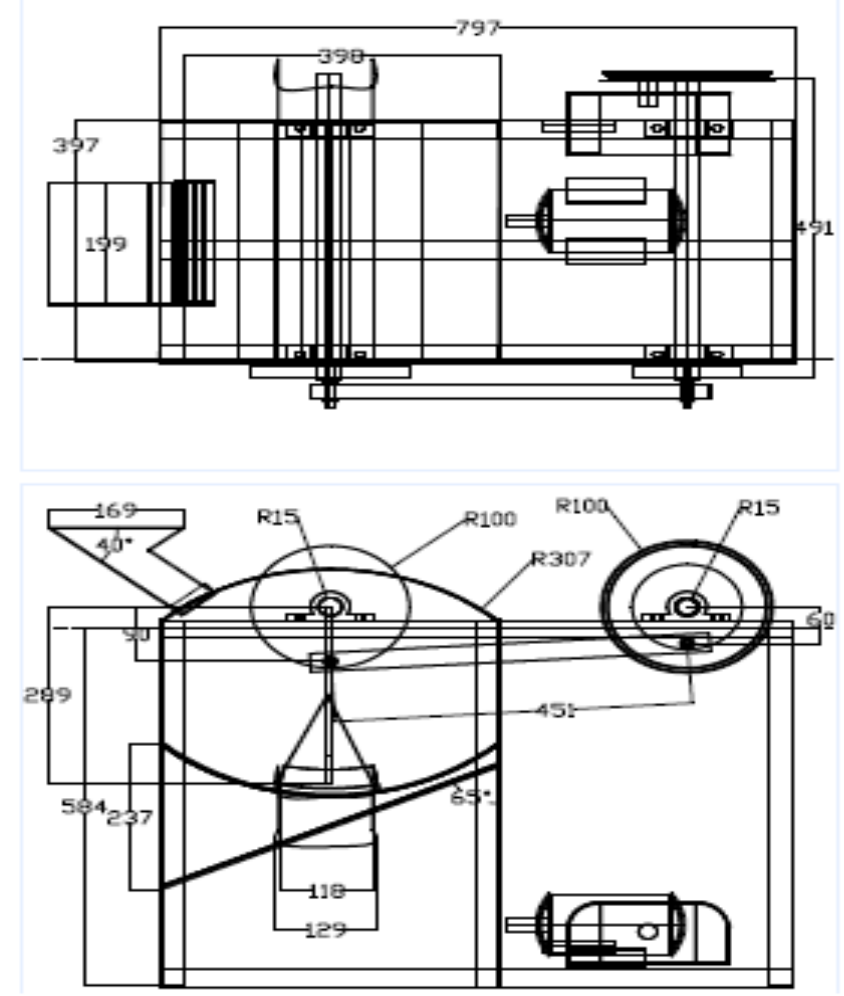

attrition or shearing force principle. The peeling is achieved due to the friction between the ginger and the abrasive surface of peeling chamber; ginger and abrasive surface of the shoe pad and as well friction among the rhizomes. The shoe which comes in contact with the ginger has conical projection on its surface. The machine prime mover is a $3 \mathrm{hp}$ internal combustion, petrol engine. The shoe is attached to an adjustable arm which is then attached to the shaft. The shaft is connected to the cranking mechanism through a connecting rod. As the pulley makes a rotary motion, this motion is converted to the oscillatory motion of the shaft, the arm and the shoe pad which are attached rigidly together. The shoe and peeling chamber have a clearance which depends on the geometric mean diameter of the ginger rhizomes (of $42.10 \mathrm{~mm}$, given by [6]). As the rhizomes are trapped in between the abrasive shoe pad and the abrasive peeling chamber; and the shoe pad performs an oscillating motion, the rhizomes are being peeled due to the friction between the ginger and the abrasive surface of peeling chamber; ginger and abrasive surface of the shoe pad and as well friction among the rhizomes. The peels fall through the openings on the peeling chamber through the discharge chute while the peeled ginger rhizomes are collected from the discharge gate.

Figure 2: Orthographic views of developed ginger rhizomes peeling machine 

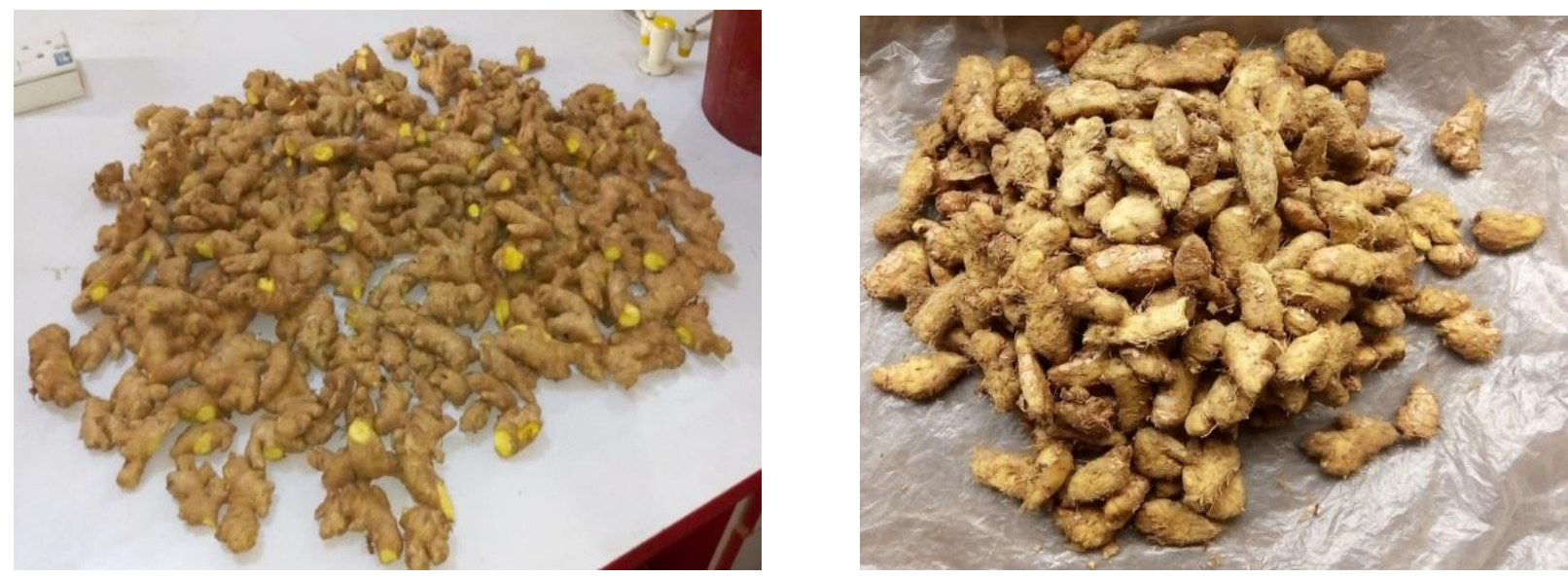

Figure 3: Ginger rhizomes before and after peeling

\subsection{Performance Evaluation}

Ginger rhizomes used for this study was sourced from Ntigha market in Isialangwa L.G.A Abia State. The rhizomes were cleaned and prepared ready for peeling. The machine was set into operation and allowed for 2 minutes before $5 \mathrm{~kg}$ of ginger rhizomes were fed into the peeling chamber through the hopper. The time taken for peeling and peeling shaft speed were noted and recorded. The peeled ginger and peels were collected and weighed independently. The feed rate and moisture content were also determined. Each of the tests was replicated two times and at three levels of speed, moisture content and feed rate. The peeling speed, feed rate and moisture content were taken as independent parameters for this study. Three levels of peeling speed $S_{1}, S_{2}$ and $S_{3}(230,270$ and $300 \mathrm{rpm})$ were chosen in order to determine the optimum speed required in peeling ginger rhizomes and three levels of feed rate were taken $F_{1}, F_{2}$ and $F_{3}(54,68$ and 73 $\mathrm{kg} / \mathrm{hr}$ ). Also, three levels of moisture content were taken as $M_{1}, M_{2}$ and $M_{3}(70,75$ and $80 \% w b)$. These parameters gave a $3 \times 3 \times 3$ factorial experiment replicated two times. This gave a total of 27

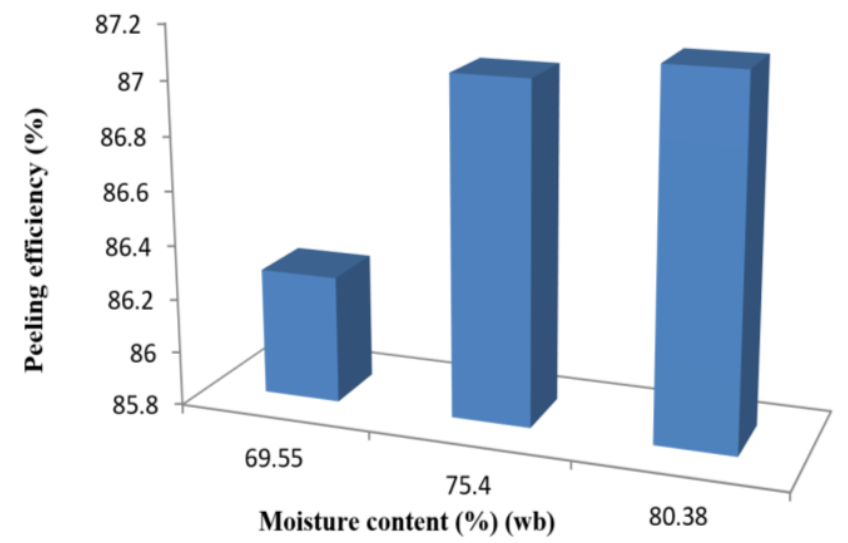

Figure 4: Effect of moisture content on peeling efficiency

Nigerian Journal of Technology, treatment combinations and 54 numbers of observations. The values obtained were used to calculate the performance parameters.

\section{RESULTS AND DISCUSSIONS}

3.1 Effect of moisture content, feed rate and peeling speed on Peeling Efficiency

It was observed that the peeling efficiency increased $(86.27 \%-87.13 \%)$ with an increase in moisture content as shown in Fig. 3. The peeling efficiency decreased $(87.56 \%-81.69 \%)$ with an increased feed rate (Fig. 4) which could be as a result of the increase in the amount of ginger fed into the machine and increase in residence which aids in the effective peeling of the rhizomes. Also, the peeling efficiency increased (86.64 \% - $87.8 \%$.) with an increased peeling speed as shown Fig. 5; which agrees with the report by [7] that peeling efficiency increased with increase in the speed of inner drum. The analysis of variance (ANOVA) showed that moisture content and speed had no significant difference on peeling efficiency while feed rate had a significant effect at $p<0.05$ level.

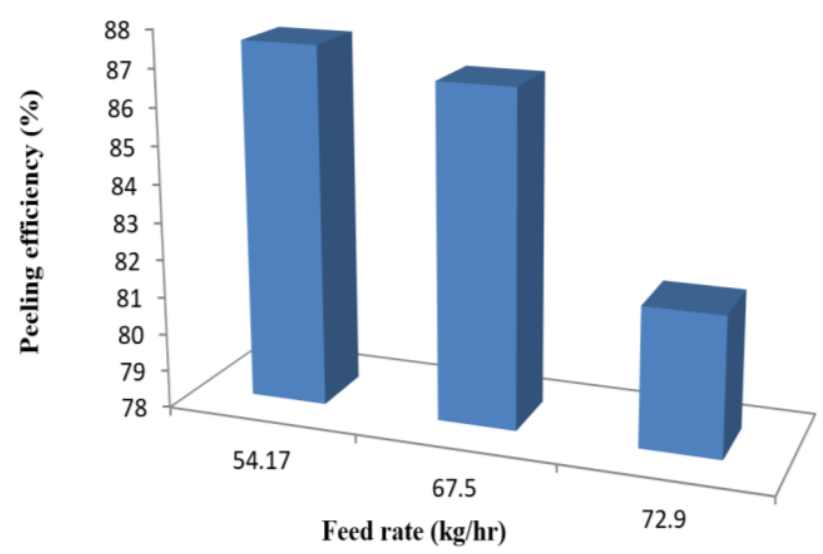

Figure 5: Effect of feed rate on peeling efficiency

Vol. 38, No. 2, July 2019 


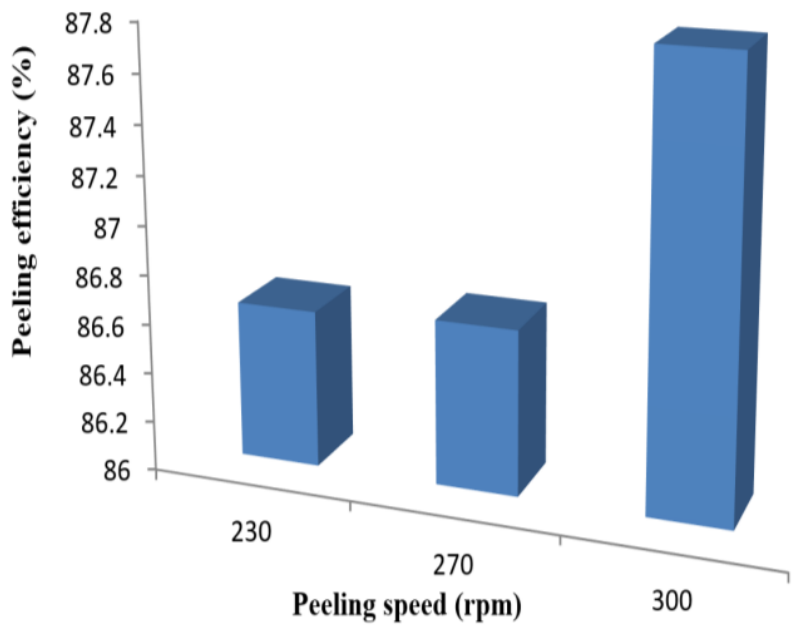

Figure 6: Effect of peeling speed on peeling efficiency

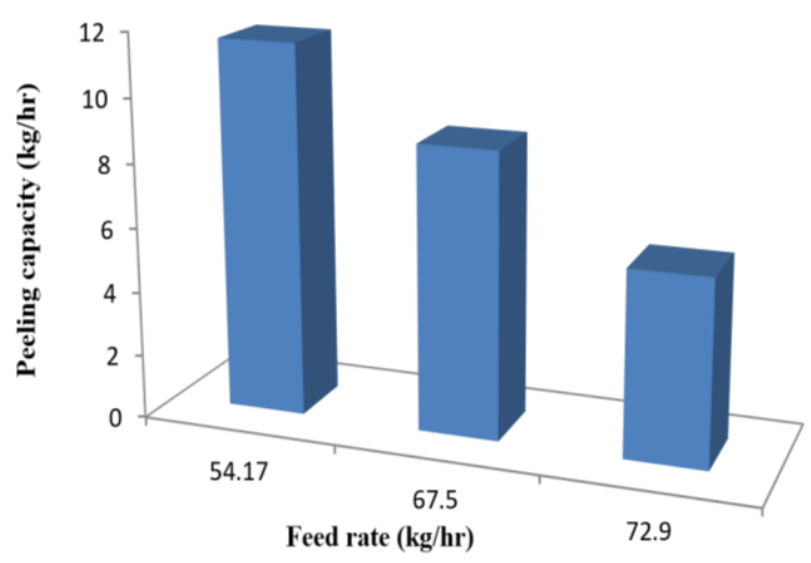

Figure 8: Effect of feed rate on peeling capacity

\subsection{Effect of moisture content, feed rate and peeling speed on Peeling Capacity}

It was found that the peeling capacity decreased $(8.85 \mathrm{~kg} / \mathrm{hr}-8.77 \mathrm{~kg} / \mathrm{hr})$ with a decrease in moisture content as presented in Fig. 6 . In Fig. 7, the peeling capacity increased $(5.78 \mathrm{~kg} / \mathrm{hr}-11.61 \mathrm{~kg} / \mathrm{hr})$ with a decrease in feed rate which could be as a result of the increase in the amount of ginger fed into the machine and time to finish feeding. At the same time, peeling capacity was highly achieved from $8.54 \mathrm{~kg} / \mathrm{hr}$ to $8.69 \mathrm{~kg} / \mathrm{hr}$ with an increase in peeling speed as shown in Fig. 8. This may be due to the increase in friction between the pad and the rhizomes. The analysis of variance (ANOVA) of moisture content, feed rate and peeling speed on peeling capacity had a significant difference at $p<0.05$ level.

\subsection{Effect of moisture content, feed rate and peeling speed on Percent Damage}

In Fig. 9, it was noticed that the percent damage decreased $(10.26 \%-7.73 \%)$ with an increase in moisture content. Percent damage increased from

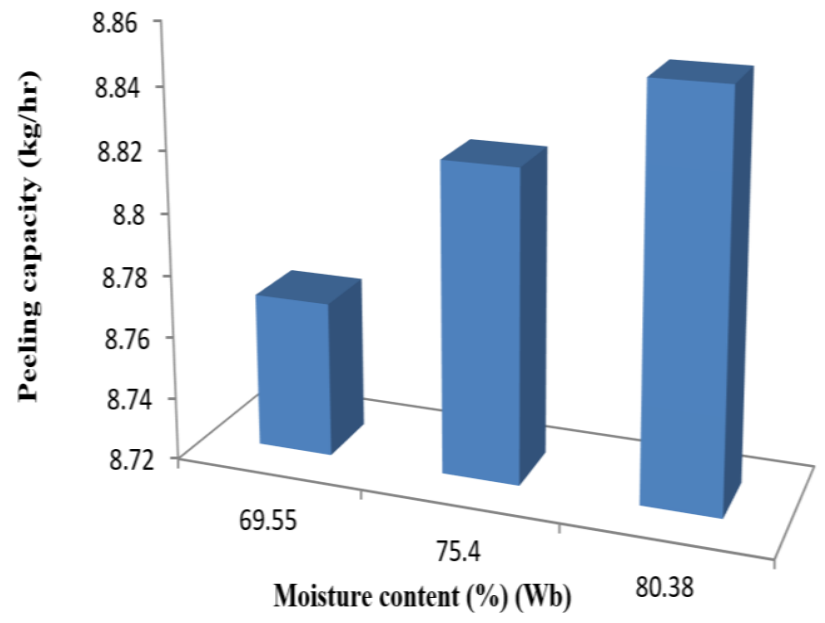

Figure 7: Effect of moisture content on peeling capacity

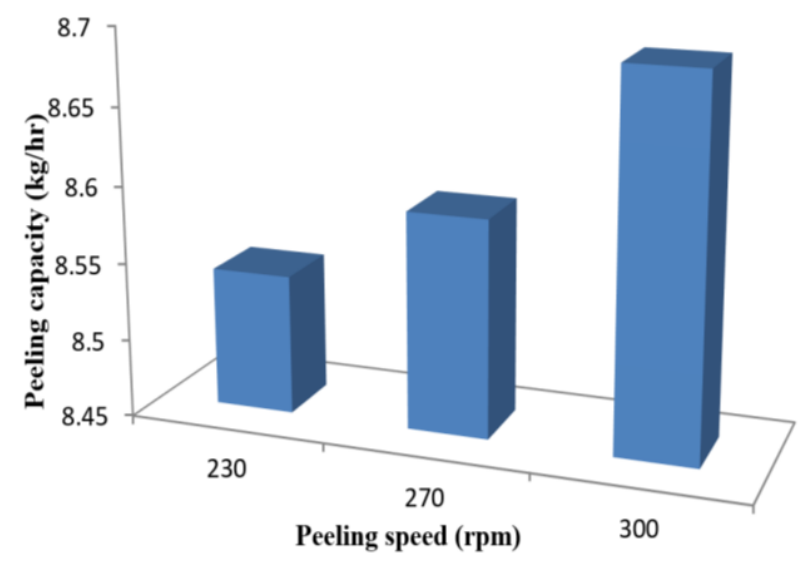

Figure 9: Effect of peeling speed on peeling capacity

$6.62 \%$ to $11.78 \%$ with an increase in feed rate as presented in Fig. 10. Also, the percent damage increased $(8.51 \%-8.64 \%)$ with an increase in peeling speed as shown in Fig. 11. This result is in consonance with the report of [7] that the material loss also increased with increase in the speed of inner drum. The analysis of variance (ANOVA) showed that moisture content, feed rate and peeling speed had a significant difference on percent damage at $p<0.05$ level.

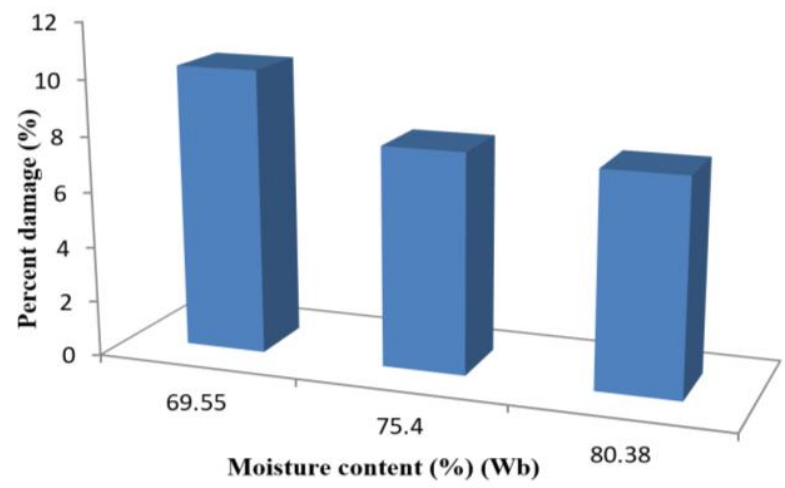

Figure 10: Effect of moisture content on percent damage

Vol. 38, No. 2, July 2019 


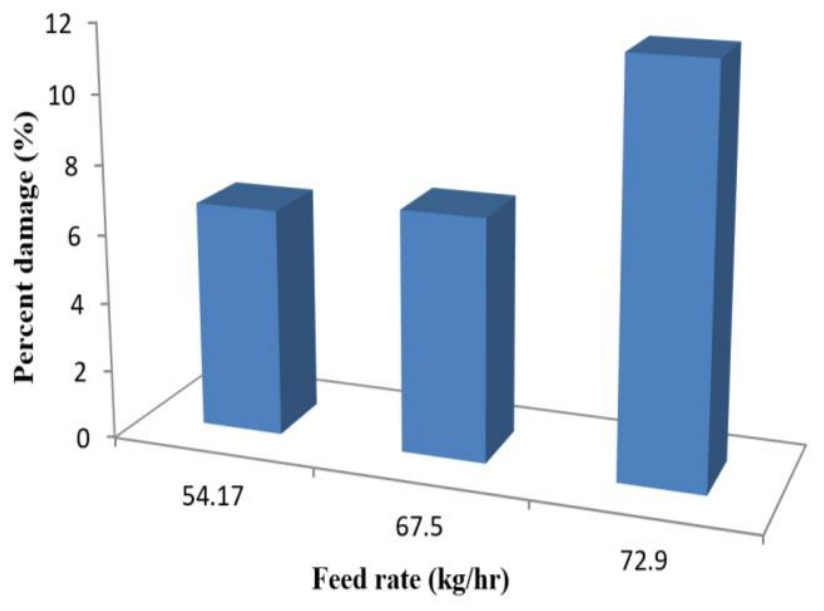

Figure 11: Effect of feed rate on percent damage

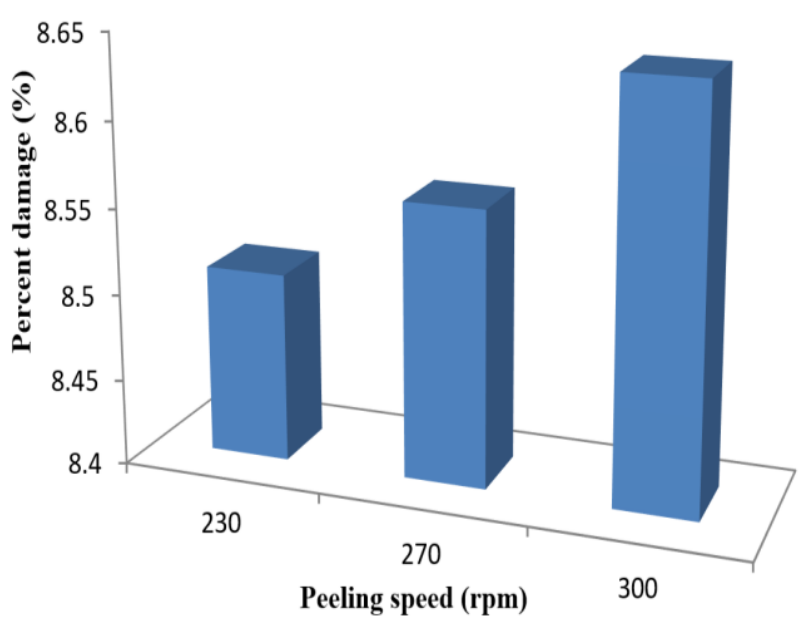

Figure 12: Effect of peeling speed on percent damage

\section{CONCLUSIONS AND RECOMMENDATIONS}

The following conclusions could be drawn based on the results of this study:

$>$ A motorized ginger rhizomes peeling machine made from readily available materials, cheap and within the buying capacity of local farmers (which cost about $150-200,000$ naira compared to the imported ones which costs about $2-2.9$ million Naira) was designed and developed.

$>$ Peeling efficiency increased with an increase in moisture content and peeling speed and also decreased with an increase in feed rate.

> Peeling capacity decreased with a decrease in moisture content, increased with a decrease in feed rate and increased with an increase in peeling speed.
$>$ Percent damage decreased with an increase in moisture content, increased with an increase in feed rate and increased with an increase in peeling speed.

$>$ Moisture content and peeling speed had no significant difference on peeling efficiency while feed rate had a significant effect.

> For a maximum peeling efficiency, peeling capacity and minimum percent damage, an optimum moisture content of $75 \%$, feed rate of $68 \mathrm{~kg} / \mathrm{hr}$ and peeling speed of $270 \mathrm{rpm}$ are recommended.

$>$ A full rotation of the shoe pad and a shallow depth of the peeling chamber should be used in future improvement of the machine for easy turning of the ginger rhizomes and attainment of much higher efficiency.

$>$ Due to finger-like nature of ginger rhizomes, a knife was used to cut the fingers before peeling. Future improvements on ginger peeling machine should incorporates a tool to take care of the fingers for higher peeling efficiency.

\section{REFERENCES}

[1] Entrepinoys. "Ginger production with cost analysis" at http://www.entrepinoys.com/ ginger. Retrieved 4th June, 2010.

[2] KADP. "Production of Ginger: an extension guide". Kaduna State Agriculture Development Project, Kaduna, 2000.

[3] KADP. Annual report of Kaduna State Agricultural Development Project, Kaduna, 2004.

[4] Bernard, A. "Diseases, Pest and other Factors Limiting Ginger Production in River State: Paper Delivered during the Agricultural Product Development Strategy Workshop organized by Uptonville Foundation under the aegis of Rivers State Sustainable Development Agency (RSSDA), 2008.

[5] Ebewele, R. O. and Jimoh, A. A. "Local Processing of Ginger Prospects and Problems" Proceedings of the First National Ginger workshop. Umudike, Nigeria, 1988, pp 22-23.

[6] Simonyan, K. J., Ehiem, J. C., Eke, A. B., Adama, J. C. and Okpara, D. A. "Some Physical Properties of Ginger Varieties", Journal of Applied Agric. Research, 5 (1), 2013, pp 73-79. 
[7] Jayashree, E. and Visvanathan, R. "Studies on Development of Concentric Drum, Brush Type Ginger Peeler", Agric Mechanization in Asia, Africa and Latin America, 45(4), 2014, pp 82-87.

[8] Onu, L. T. and Okafor, G. I. "Effect of Physical and Chemical Factor Variations on the Efficiency of Mechanical Slicing of Nigerian Ginger", J. Food Eng. 56(2), 2002, pp 43-47.

[9] Yiljep, Y., Fumen, G. and Ajisegiri, E. "The Effects of Peeling, Splitting and Drying on Ginger Quality". Agricultural Engineering International: CIGR E Journal. Vol.7, 2005, pp 30-33.

[10] Agrawal, Y. C., Hiran, A. and Galundia, A. S. "Ginger Peeling Parameters", Agric Mechanisation in Asia, Africa and Latin America, 18(2), 1987, pp 59-62.
[11] Ali, Y. G. C., Jain, S., Kapdi, S., Agarwal, Y. C. and Bhatnagar, S. "Development of Brush Type Ginger Peeling Machine", Agric Mechanisation in Asia, Africa and Latin America, 22 (2), 1991, pp 71-73.

[12] Rajput, R. K. Elements of Mechanical Engineering, New Delhi, Lakshmi publishers, 2013.

[13] Khurmi, R. S. and Gupta, J. K. Machine Design, New Delhi, S. Chand, Limited. Eurasia publishing house. 25th Edition, 2012.

[14] Khurmi, R. S. and Gupta, J. K. Machine Design, Eurasia Publishing House (PVT) India, 2005. 